\title{
ASSESSMENT OF THE POSSIBILITY OF APPLYING CERAMIC MATERIALS IN COMMON RAIL INJECTION SYSTEMS
}

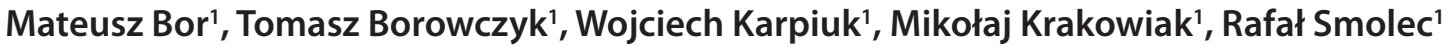 \\ Poznan University of Technology, Faculty of Machines and Transport, Institute of Combustion Engines \\ and Transport, 61-138 Poznań, Piotrowo 3 str., e-mails: mateusz.j.bor@doctorate.put.poznan.pl, \\ wojciech.karpiuk@put.poznan.pl, tomaszborowczyk@wp.pl, rafal.s.smolec@doctorate.put.poznan.pl
}

Received: 2018.01.15

Accepted: 2018.02.01

Published: 2018.03.01

\begin{abstract}
Ceramic materials are currently interesting as substitutes for the metals traditionally used for engineering applications. This paper focuses on a comparison of ceramic materials: corundum (alumina, $\mathrm{Al}_{2} \mathrm{O}_{3}$ ) and silicon carbide (solid-state sintered) - SSiC with bearing alloy steel $100 \mathrm{Cr} 6$, i.e. the material used to make pistons and cylinders of pumps in common rail injection systems. The article is divided into two parts. In the first part, the aforementioned materials are characterized and their properties compared from the perspective of their application in piston-cylinder assemblies of injection pumps. The second part concerns analysis conduct by means of the finite element method and a specialized simulation environment, based on comparing ceramic materials and bearing steel. This comparison was conducted by using a CAD strength model of a piston in a specific application, being a pump with CP3 design. Simulation results confirmed the beneficial qualities of ceramic materials - the level of material deformation is lower for ceramics in comparison to steel.
\end{abstract}

Keywords: ceramic materials, common rail, injection systems.

\section{INTRODUCTION}

The development of modern injection systems used in Diesel engines is determined by rigorous emissions standards. This means that pumps must generate higher injection pressures in order to improve the fuel spraying process. This, in turn, translates to better evaporation and mixing with the air, making it possible to obtain a more homogeneous mixture.

One of the trends that can be seen in injection pump designs is limiting the number of pumping sections - the first generation og Bosch injection pumps (CP1) had three sections, while the latest solutions (e.g. CP4) are equipped with one or two pumping sections (engines in $\mathrm{V}$ configuration). Limiting the number of sections reduces the surface area of piston-cylinder pairs and reduces friction losses on one hand, and on the other, increases the mechanical loads acting on the system.

This in combination with very high pressures, currently reaching up to 2500 - 3000 bar, results in greater material requirements posed toward elements of injection pump subassemblies. Elements of piston-cylinder pairs are being made from increasingly advanced materials in order to guarantee the proper lifetime. When fuel is being pumped, compressive loads are the main type of load acting on a piston-cylinder pair. Studies conducted by Kałdonski [8] showed that this is the load type that contributes most to accelerating the process of piston-cylinder wear. The mechanism of this process is mainly based on abrasion caused by mineral contaminants in fuel with a hardness greater than that of the material of the piston-cylinder pair. According to Kałdoński, grains with a size of approx. $10 \mu \mathrm{m}$ are primarily responsi- 
ble for abrasive wear. Under high pressure, elements of the piston-cylinder pair are subjected to plastic strain (compression), which increases radial clearance from the designed $2-4 \mu \mathrm{m}$ to over $10 \mu \mathrm{m}$. Contaminants of larger sizes are unable to clear the gap that is formed and become jammed, while those of smaller sizes are either not captured within the gap at all or only increase roughness without causing ridging. Considering the above, fuel would have to be purified of contaminants with sizes of approx. $10 \mu \mathrm{m}$ in order to reduce the wear on piston-cylinder surfaces and increase the reliability of fuel pumps, which is currently not an easy task. Another possibility is to apply super-hard engineering ceramics in the piston-cylinder designs where abrasive grains could not become caught.

Figure 1 presents examples of the strength of material groups, with a particular emphasis on the ceramics group, which contains diamond - the hardest material known to man, but also materials like corundum (alumina) $\left(\mathrm{Al}_{2} \mathrm{O}_{3}\right)$ and silicon carbide ( $\mathrm{SiC})$, the strength of which significantly exceeds known engineering metal alloys. So it is understandable that these materials are gaining popularity and are increasingly finding applications in high-pressure fuel pump designs. This is primarily due to increased abrasion resistance and toughness, thanks to which growth of radial clearance in the piston-cylinder pair is minimized during the pump's operation, and in consequence, no abrasive grains with a diameter of approx. $10 \mu \mathrm{m}$ get into the gap, while the rest do not cause ridging as they are broken up due to the greater strength of the constructional material.

\section{CHARACTERIZATION OF $\mathrm{AL}_{2} \mathrm{O}_{3}$ AND SSIC IN REFERENCE TO PISTON-CYLINDER PAIRS APPLIED IN INJECTION SYSTEMS}

Later in this article, assessment of the possibility of applying ceramics in high-pressure pumps will be conducted on the basis of a comparison of ceramics: corundum (alumina) $\left(\mathrm{Al}_{2} \mathrm{O}_{3}\right)$ and silicon carbide (solid-state sintered) - SSiC with bearing alloy steel $100 \mathrm{Cr} 6$, i.e. the material used to make pistons and cylinders of pumping sections in common rail injection pumps.

Aluminum oxide, also known as corundum, is characterized by properties suitable for constructional applications, particularly in its polymorphic alpha variety $\left(\alpha-\mathrm{Al}_{2} \mathrm{O}_{3}\right)$ [12]. This variety, crystallized in a hexagonal configuration, has good strength and tribological properties, although they are dependent on the progression of the sintering process [11]. Besides alumina ceramics, silicon carbide exhibits other valuable

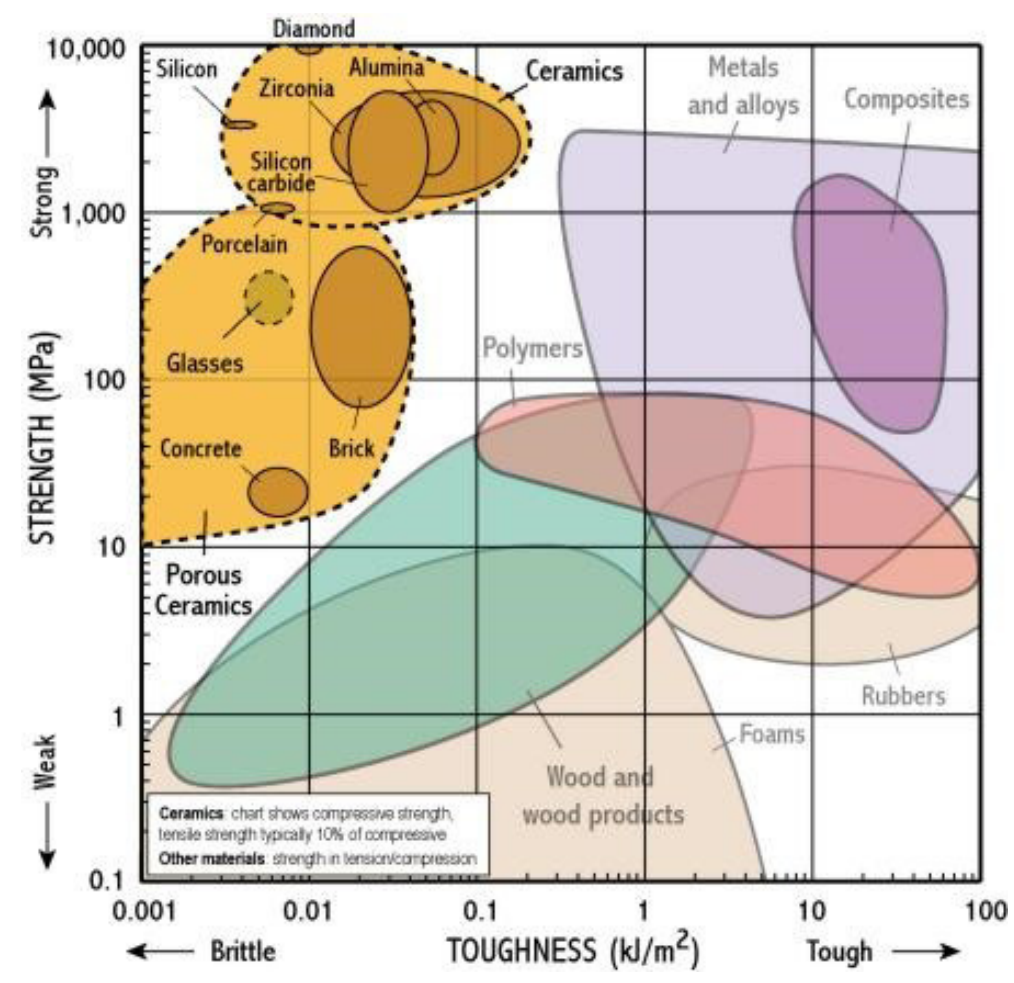

Fig. 1. Strength and toughness curves of selected material groups [6] 
properties from the perspective of strength. This material is characterized by similar, and even better, material parameters than $\mathrm{Al}_{2} \mathrm{O}_{3}$ - it is characterized by greater hardness and thermal shock resistance, better mechanical properties, including e.g. strength. When selecting a material for a specific application, one must consider its mechanical properties above all. The materials of pistoncylinder pair elements should be characterized by appropriate behavior under present loads. Thus, attention should be paid to the stress-strain curve of aluminum oxide (fig. 2).

Ceramic materials are susceptible to brittle cracking. This is complete contrast to metals, in which a certain plastic strain range can be observed. This is due to the structure of ceramics covalent bonds are directional. Moreover, ceramics contain defects like cracks, pores and voids, and specimens are destroyed within the elastic strain range [11]. These structural discontinuities contribute to reduced tensile strength and cracking under the action of tensile stresses, lower than assumed on the basis of interatomic bonds. The voids mentioned above then expand, which leads to reduced load-carrying capacity [12]. Ceramics are characterized by greater compressive strength compared to tensile strength $\left(\mathrm{R}_{\mathrm{C}} \cong 15 \cdot \mathrm{R}_{\mathrm{m}}\right)[12]$.

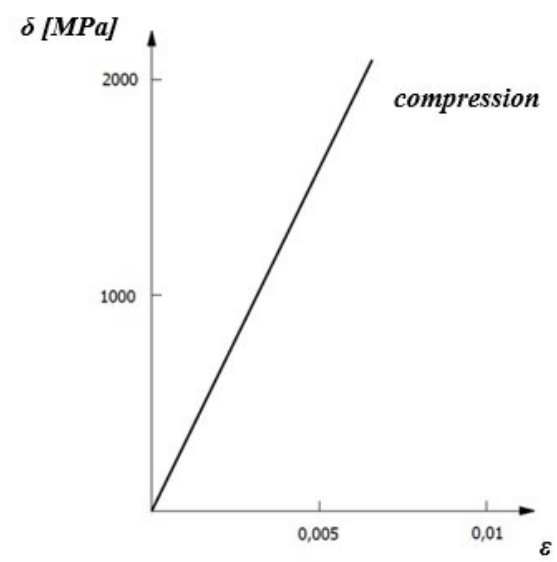

Therefore, it is beneficial to apply engineering ceramics in the pistons of sectional pumps but also in drive rollers (present e.g. in the CP4 pump between the drive cam and sectional piston), since these elements carry compressive loads due to the nature of their work.

Normalized hardness, stress intensity factor and other parameters defining the mechanical properties of $\mathrm{Al}_{2} \mathrm{O}_{3}$ and $\mathrm{SSiC}$ as well as $100 \mathrm{Cr} 6$ steel, such as: compressive strength, flexural strength and Young modulus are given in table 1 in the same order.

High hardness (fig. 3) and resistance to abrasion are typical for ceramic materials. They owe this to their structure, in which a lattice with ion bonds poses resistance to moving dislocations [8]. Initiation of dislocation migration is very difficult, and such linear defects are the cause of permanent plastic deformation. Determining hardness by various available methods is tantamount to determining the state of plasticity, thus it can be accounted for by means of strains. To achieve initiation of dislocations, high stresses tangent to bonds are required to break the bonds [8]. The critical stress initiating dislocation slipping is high for corundum ceramic, on the order of $\mathrm{E} / 30$, but for metals, it is only E/1000 [1]. However,

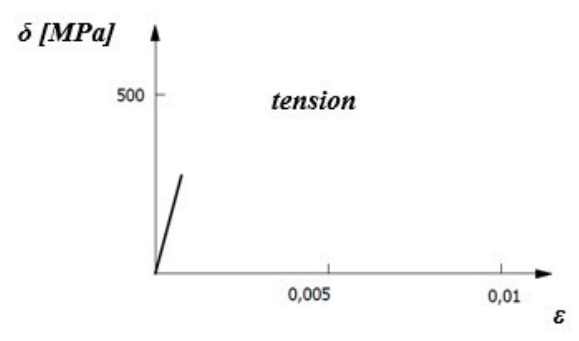

Fig. 2. Stress-strain curves of Al2O3 for compression (left side) and tension (right side) [1]

Table 1. Maximum values of compared properties of ceramic materials and $100 \mathrm{Cr} 6$ steel $[3,5,7]$

\begin{tabular}{|c|c|c|c|c|c|c|}
\hline material & $\begin{array}{c}\text { normalized } \\
\text { hardness } \\
\text { HK } 0.1 \\
\text { [GPa] }\end{array}$ & $\begin{array}{c}\text { Vickers } \\
\text { hardness HV }\end{array}$ & $\begin{array}{c}\text { stress intensity } \\
\text { factor } \\
\mathrm{K}_{\mathrm{IC}} \\
{\left[\mathrm{MPa} \mathrm{m}^{1 / 2}\right]}\end{array}$ & $\begin{array}{c}\text { compressive } \\
\text { strength } \\
\mathrm{R}_{\mathrm{c}} \\
{[\mathrm{MPa}]}\end{array}$ & $\begin{array}{c}\text { flexural } \\
\text { strength } \mathrm{R}_{\mathrm{g}} \\
\text { [MPa] }\end{array}$ & $\begin{array}{c}\text { Young } \\
\text { modulus E } \\
\text { [GPa] }\end{array}$ \\
\hline $\begin{array}{c}\mathrm{Al}_{2} \mathrm{O}_{3} \\
\mathrm{~F} 99.7\end{array}$ & 23 & 1650 & $4.2 \div 6.0$ & 3500 & 350 & 380 \\
\hline $\mathrm{SSiC}^{*}$ & 24.5 & 2540 & 4.0 & $>2500$ & 400 & 430 \\
\hline 100Cr6 steel & - & 800 & $15.4 \div 18.7$ & - & - & 212 \\
\hline
\end{tabular}

* Ekasic $^{\circledR} \mathrm{F}$ 

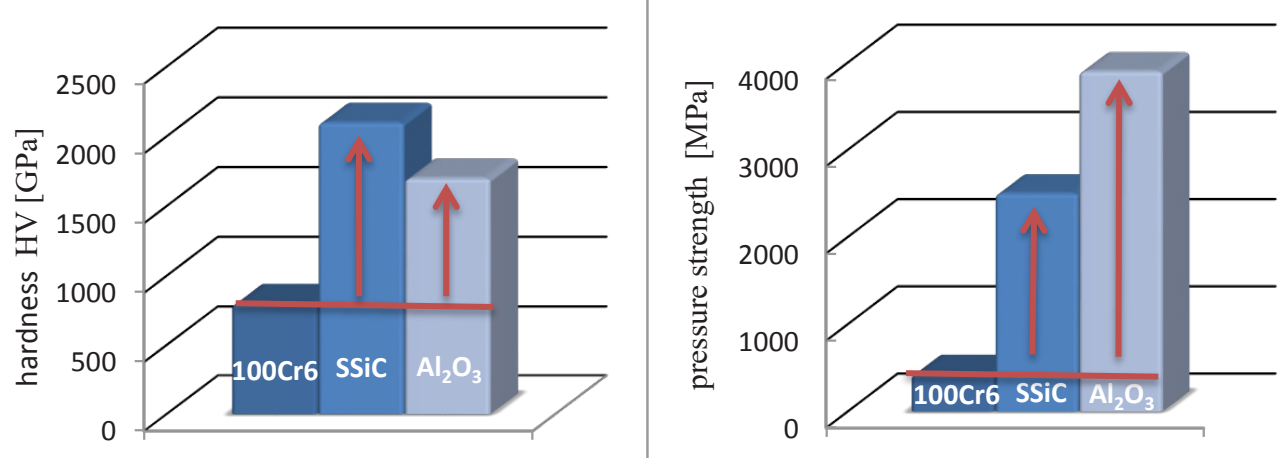

Fig. 3. Hardness and pressure strength of selected materials: $100 \mathrm{Cr} 6, \mathrm{SSiC}$ and $\mathrm{Al}_{2} \mathrm{O}_{3}$

$\mathrm{Al}_{2} \mathrm{O}_{3}$, which has ion bonds, also contains directions in which atom dislocations are absolute and resistance is lower $[1,8]$. Attention should also be paid to SSiC's high hardness, even higher than that of $\mathrm{Al}_{2} \mathrm{O}_{3}$ and significantly exceeding that of metals. Young's modulus, which is linked to this and defines resistance to elastic strain, amounts to approx. $430 \mathrm{GPa}$. At the same time, it is not dependent on the duration of load. The type of bonds present in and building the structure has an impact on hardness and strength, which are essentially interdependent properties. As mentioned earlier, these are covalent bonds that pose strong resistance to initiation and migration of dislocations [11]. However, similarly to $\mathrm{Al}_{2} \mathrm{O}_{3}$, silicon carbide is characterized by a certain strength distribution describing the possibility of destruction even at non-critical stresses.

The stress intensity factor $-\mathrm{K}_{\mathrm{IC}}$ value for ceramic materials is an important factor from the perspective of injection pumps, and it is over 3 times lower than the value for $100 \mathrm{Cr} 6$ steel. The definition of this factor must be cited, according to which it defines the load initiating uncontrolled crack propagation in cross-sections [4]. This is an adverse effect of impeding dislocation slip. Ceramics are distinguished by lower crack resistance than metals due to their limited capability to sustain plastic strains, and thus also by lower impact resistance. Low crack resistance, considered as the high brittleness of engineering ceramics may be the primary obstacle in constructional applications of the designed elements. Products are frequently destroyed during operation or subject to premature damage. It becomes important then to avoid structural discontinuities, e.g. microcracks, by preserving low tolerance to the presence of defects [11]. Even cracks on the micro scale, within the tolerance range, smaller than critical cracks, may grow and contribute to further propagation
[12]. Compressive and flexural strength must also be observed closely - in the ceramic materials under consideration, strength against pressure loading is much greater than that presented by metals $[8,11,12]$.

Cooperation of piston-cylinder pairs in sliding contact requires high resistance to various types of wear from their surfaces. The condition of products' surface structure has an effect on abradability. Roughness becomes important in the description of this condition, however in the case of engineering ceramics, this approach has limited application. This is due to empty "spaces" in the material, i.e. voids, pores, etc., which significantly change the distribution of values. However, other parameters related to the load-carrying and capacity of the lubricating agent $\left(\mathrm{R}_{\mathrm{pk}}, \mathrm{R}_{\mathrm{k}}\right.$, $R_{v k}$ ) enable description of the surface [3]. Citing studies of wear in ceramics [3], finishing surface treatment is an important aspect as it has a significant effect on roughness. The structure of aluminum oxide depends on the sintering process, with an average grain diameter of approx. $7.5 \mu \mathrm{m}$ [3]. Meanwhile, this value is approx. $1.9 \mu \mathrm{m}$ for $\mathrm{SSiC}$, so $\mathrm{Al}_{2} \mathrm{O}_{3}$ is characterized by greater roughness. At the same time, however, both materials exhibit relatively deep material losses caused by torn out grains, although on a polished corundum surface, the number of pits caused by such losses is lower, and there are still less in the case of SSiC, where these areas are smallest.

The friction coefficient arises directly from the quality of the surface and is an important aspect in fitting elements of piston-cylinder pairs. In common rail injection pumps, a high length of surface overlap is applied, which has a significant impact on the tightness of the tightness of the node and on reducing losses [2]. Unfortunately, fitting accuracy also results in greater contact between surfaces and greater friction resistance, as 
well as the occurrence of intensified phenomena, e.g. heat emission. The application of ceramic materials should also be considered from the perspective of this problem. It is important to reduce the friction coefficient and thus increase the efficiency of the system while also minimizing the possibility of wear.

Studies [3] were conducted in the environment of isooctane, with poorer lubricating properties than Diesel. It was demonstrated that the surface quality of $\mathrm{Al}_{2} \mathrm{O}_{3}$ has an effect on the friction process (fig. 4). Considering the surface after polishing, the friction coefficient reaches a quasi-static state at a level of approx. 0.4 [3]. In comparison with 100Cr6 steel, these parameters have similar values, so both materials meet the same requirements. Sintered silicon carbide exhibits low surface roughness due to the achievement of a grain size of approx. $1.9 \mu \mathrm{m}$ in the pressureless sintering process [3]. Along with the proper surface treatment, this is reflected in its low friction coefficeint - after polishing, its value fluctuates at around $\mu=0.2$.

Surface hardness has a significant effect on elements in the friction node, and as it rises, the negative consequence of friction processes, including abrasion, are minimized. The application of ceramic materials leads to elimination of tribochemical wear, and so, no adhesive bonds leading to abrasion of the piston-cylinder friction pair occur.

Another matter worth touching upon in reference to the application of engineering ceramics in common rail injection systems is their chemical and corrosion resistance. The piston-cylinder kinematic pair is exposed to various chemical agents arising from the presence of the active environment that is Diesel. High resistance to chemical processes is due to the durability of structural bonds characteristic of ceramic materials. Ceramics owe their potential neutrality against chemi- cal agents to the fact that the system strives to achieve the lowest possible free energy, and this is particularly the case in oxides. These materials reach high resistance even at high operating temperatures, which becomes important in various applications requiring this property [5]. The oxidation process is important when considering this. However, in the system in question, only elevated temperature is present, since Diesel reaches temperatures on the order of $60^{\circ} \mathrm{C}$ in a high pressure pump.

The proposed ceramic materials undergo corrosion, however their resistance is much greater than that of metals, and they can be used in applications where they are exposed to corrosion. Chemical interaction is the predominant corrosion mechanism. Engineering ceramics have high resistance to the action of solvents and acids at elevated temperatures while being susceptible to the presence of fluorides (oxide ceramics) and even water vapor (no hydrothermal resistance) [5].

A summary of considerations about the properties of ceramic materials is presented in a diagram in figure 5 - the benefits of their applications in piston-cylinder pairs of injection systems are distinguished alongside the operating conditions in which these materials must work.

\section{FEM ANALYSIS}

Applications of ceramics are known in solutions of machinery and equipment, including in pumps, where they have replaced metals. Valve balls as well as rolls and bearings in pumps are made from technical ceramics. These materials also find applications in pumping sections. Finite element analysis by means of a specialized simulation environment will serve for assessment of the justification of application and properties of el-
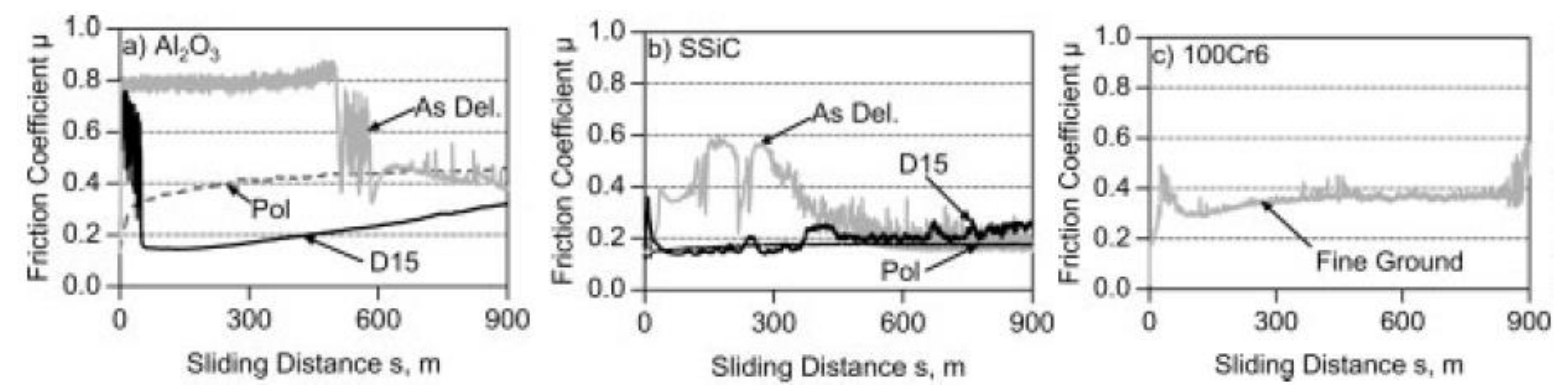

Fig. 4. Friction coefficient of the sliding node between elements made of $\mathrm{Al} 2 \mathrm{O} 3$ (a) with different surface qualities and $100 \mathrm{Cr} 6$ (b) as a function of the length of sliding contact in isooctane [3] 


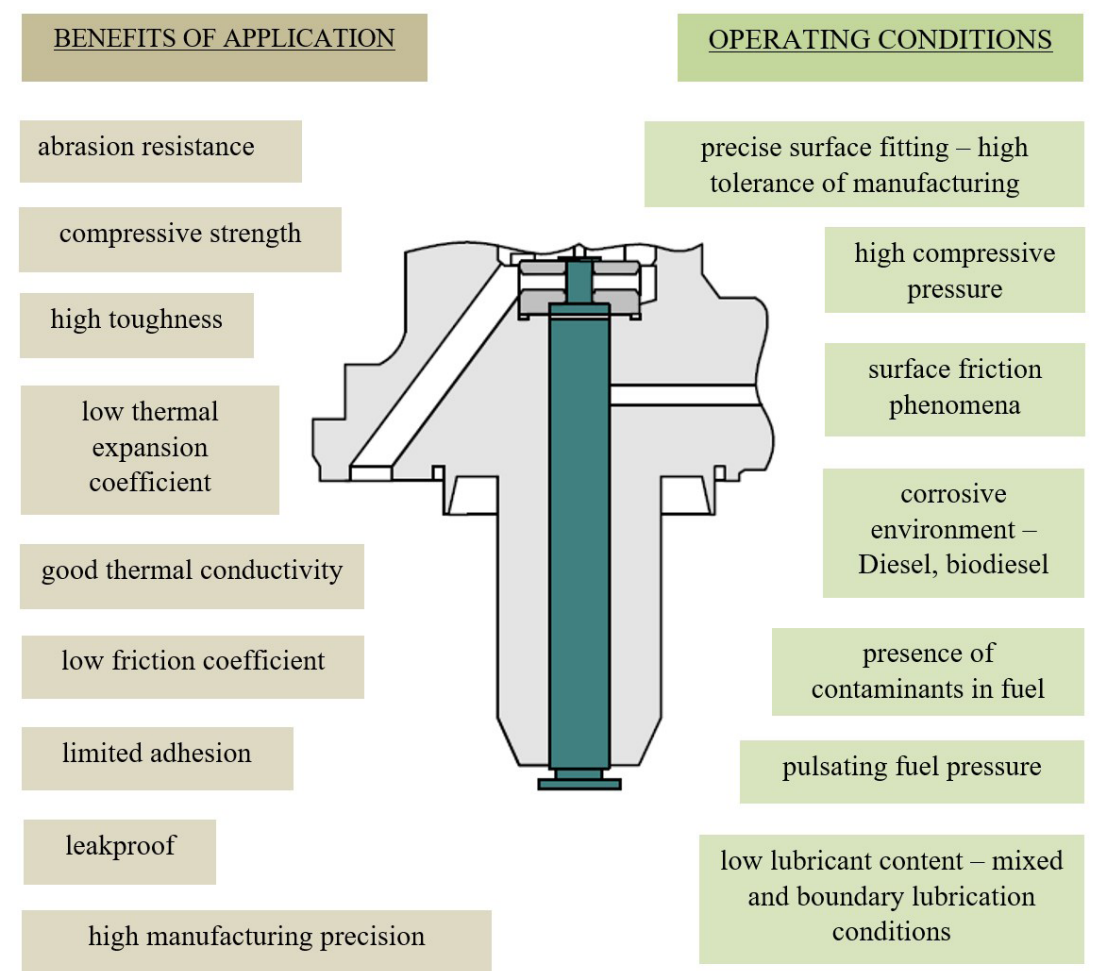

Fig. 5. Benefits of application and operating conditions of ceramic materials with respect to their application in piston-cylinder pairs of common rail injection systems

ements from the perspective of the materials used to make them. The comparison between ceramic materials, $\mathrm{Al}_{2} \mathrm{O}_{3}$ and $\mathrm{SSiC}$, will therefore be based on strength simulations of a piston CAD model in the specific application that is a CP3 pump.

Analysis of the direct transient response of the pump piston under present stresses, strains and displacements was conducted on a CAD model made in the Autodesk Inventor 2017 environment, and finite element simulations were performed in the Nastran In Cad package. Discretization of the piston made it possible to divide the model into 35584 finite elements and 55426 nodes in order to determine the progression of finite element size reduction throughout the entire geometry (fig. 6). The piston was subjected to the greatest possible pressure that can occur in the CP3 pump - 180 $\mathrm{MPa}$ at the end of the compression stroke. It was assumed that analysis will reflect the conditions in place at maximum load, however the cylinder/ pump head interaction was omitted. In this way, the piston is exposed to greater load than it actually is. The interaction between the resistance disk of the spring and the piston stem end was also omitted. Thus, attention was mostly focused on the action of pressure and its consequences. Pressure load was applied to the piston's top surface while the bottom surface of the stem end was fixed in place. Simulations were conducted on three design variants of the element, made from different materials, described in the previous subsection. Their properties were determined on the basis of source materials $[5,8]$. It was decided to collect results at the time of the highest pumping pressure according to the assumed progression of its change for the instant of time at $0.02 \mathrm{~s}$, when the maximum value of $180 \mathrm{MPa}$ was reached, since this is an analysis of variable load (fig. 7). The results of the analyzes for the selected materials are shown in the figures $6-13$.

\section{ANALYSIS OF SIMULATION RESULTS}

By means of the finite element simulation environment, the possibility of using $\mathrm{Al}_{2} \mathrm{O}_{3}$ and $\mathrm{SSiC}$ ceramic materials and $100 \mathrm{Cr} 6$ steel in a specific application was analyzed. Analysis of variable load over time was generalized as a static compression test, and so a strictly strength-based simulation, as assumed in further conclusions. The set of results is presented in table 2 .

With respect to maximum stress results, it was observed that their concentration in all variants of the element fell within the area of geometry change. 


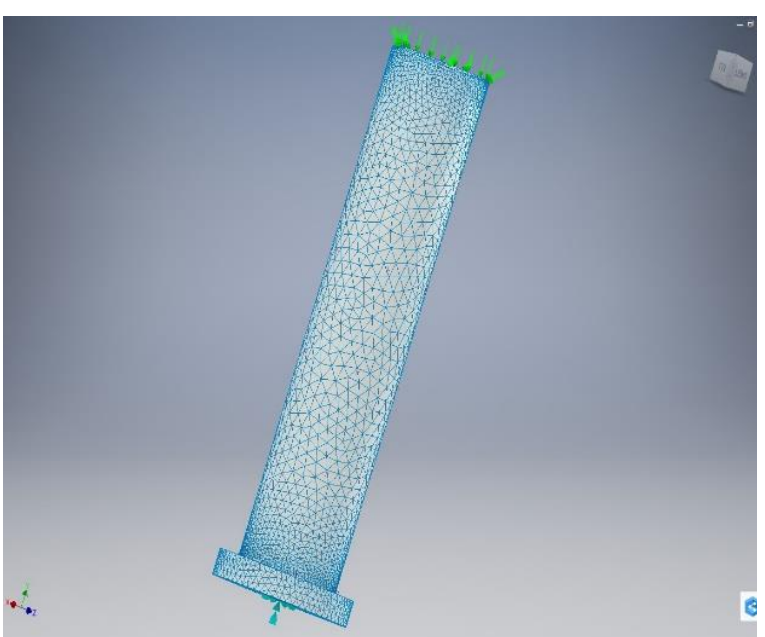

Fig. 6. Piston model with constraint discretized into finite elements

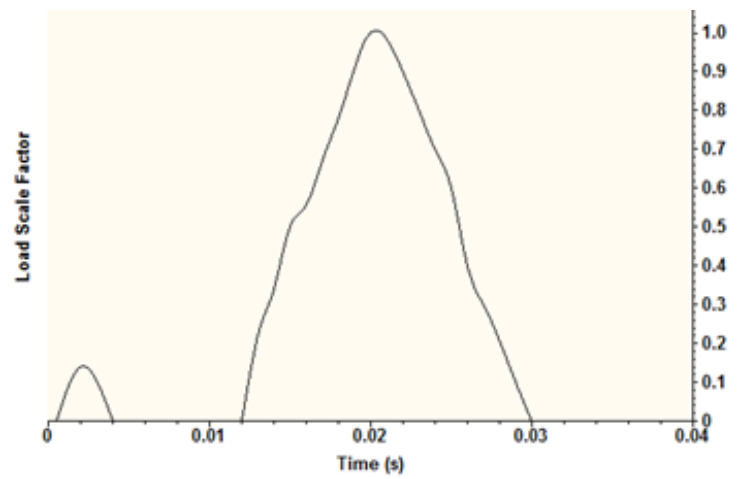

Fig. 7. Chart of the approximate progression of pressure changes acting on the piston during simulation over time

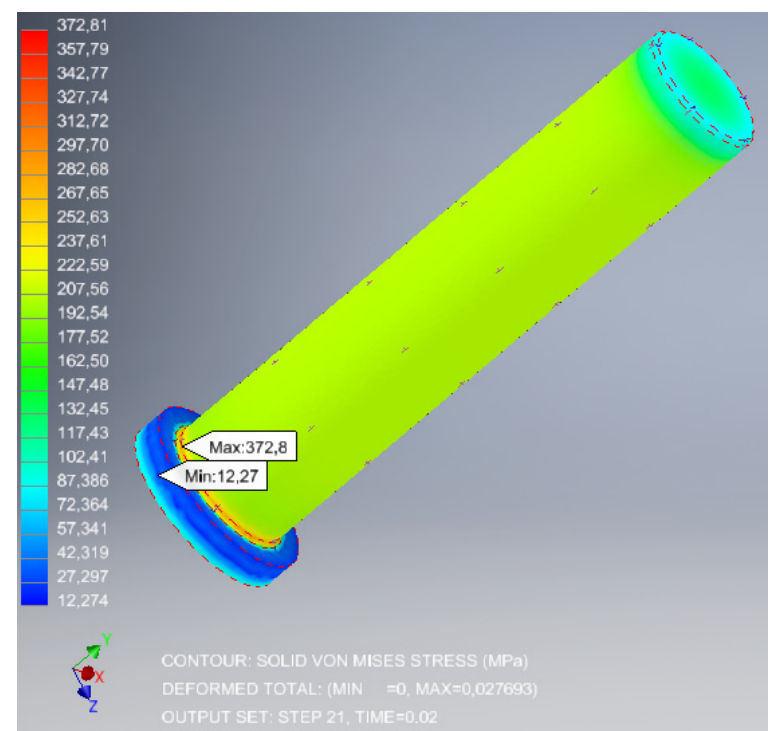

Fig. 8. Von Mises reduced stress distribution [MPa] for an element made from $100 \mathrm{Cr} 6$ bearing steel at the time of maximum pumping pressure
It is worth analyzing the case of bearing steel here. The lowest maximum reduced stress was obtained in this case, since metals are characterized by an elastic and plastic range, in contrast to ceramics. However, similarly as in the case of other materials, the concentration of the highest stresses and strains occurs near the transition of the piston's geometry to its stem end (fig. 14). In this case, reduced stresses exceed the value of critical stresses calculated analytically according to dependency (1):

$$
\begin{gathered}
\sigma_{d o p}=(0.55 \div 0.65) R_{e} \\
\sigma_{\text {red }}<\sigma_{d o p}
\end{gathered}
$$

It can be accepted that for compression, the $\mathrm{R}_{\mathrm{e}}$ parameter has similar values determined on the basis of a tensile test. A yield point of 400 $\mathrm{MPa}$ was determined in analysis for $100 \mathrm{Cr} 6$ steel, for which critical stresses are within the range of $220 \div 260 \mathrm{MPa}$, according to the dependency given above. The maximum result of simulation reached a value of $372.8 \mathrm{MPa}$, and condition (2) was not met.

Table 2. Result of analyses

\begin{tabular}{|c|c|c|c|}
\hline & $100 \mathrm{Cr} 6$ & $\mathrm{Al}_{2} \mathrm{O}_{3}$ & $\mathrm{SSiC}$ \\
\hline $\begin{array}{c}\text { max. red. von Mises } \\
\text { stresses [MPa] }\end{array}$ & 372.8 & 373.4 & 385.7 \\
\hline max. strain [-] & 0.001539 & 0.000852 & 0.000752 \\
\hline
\end{tabular}

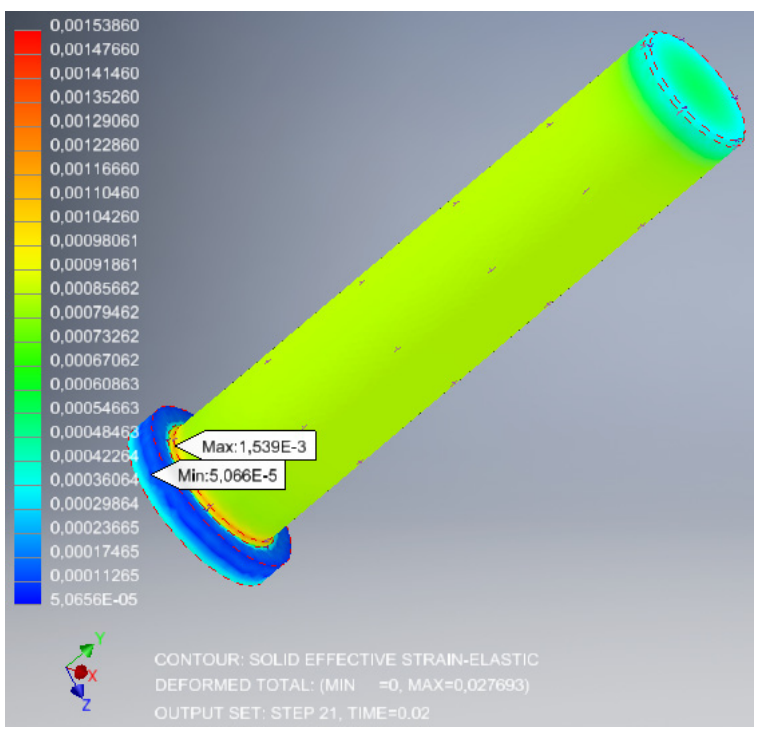

Fig. 9. Strain distribution [-] for the element made of $100 \mathrm{Cr} 6$ bearing steel 


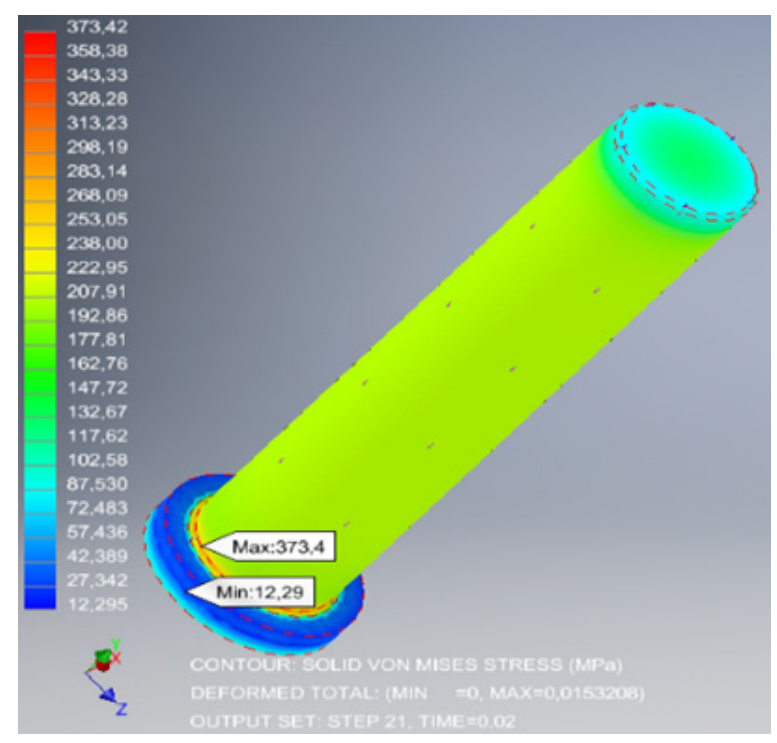

Fig. 10. Von Mises reduced stress distribution [MPa] for an element made of homogenoeus $\mathrm{A} 12 \mathrm{O} 3$ corundum ceramic at the time of maximum pumping pressure

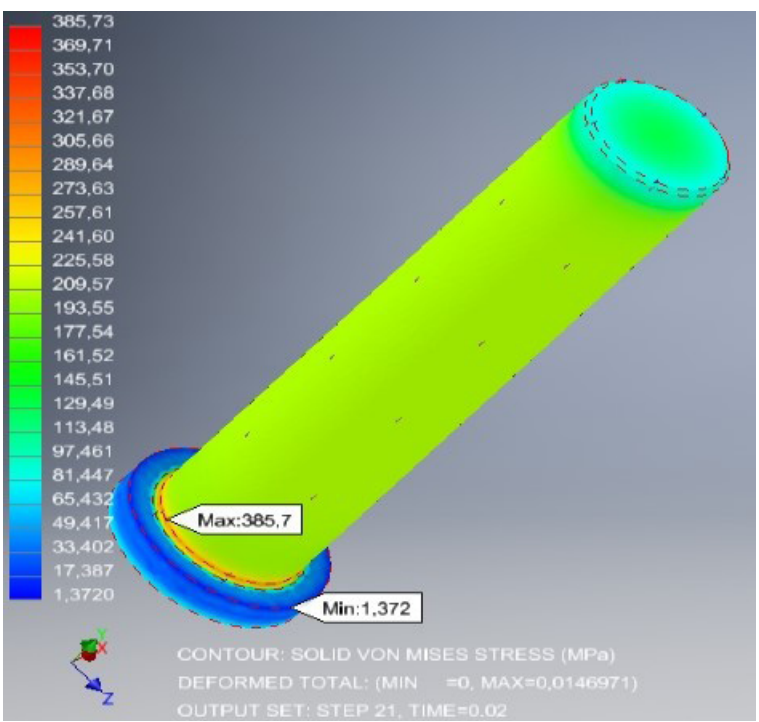

Fig. 12. Von Mises reduced stress distribution $[\mathrm{MPa}]$ for the element made from sintered silicon carbide

$\mathrm{SSiC}$ at the time of maximum pumping pressure

The consequence of the occurrence of maximum stresses in this area of the element may be weakening of the structure, and strains relative to the entire element indicate that this area is exposed to certain plastic strains. The example of a worn CP3 pump piston taken from the literature [10] (fig. 15) illustrates this problem. It caused upsetting of the material as a result of plastic strains caused by maximum pressure value and periodicity, and internal stresses exceeded critical values [10]. Loads occurring in cycles are

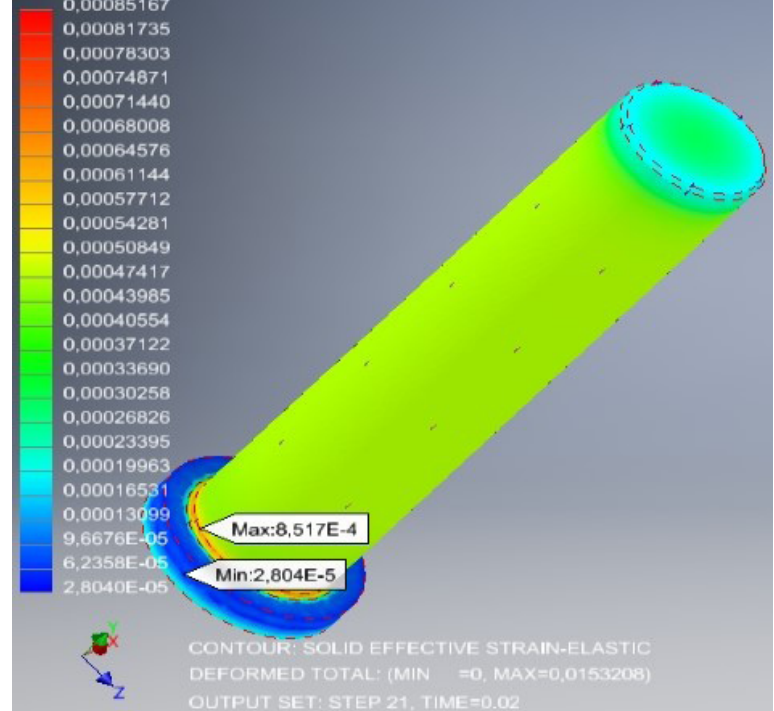

Fig. 11. Strain distribution [-] for the element made from homogeneous $\mathrm{A} 12 \mathrm{O} 3$ corundum ceramic

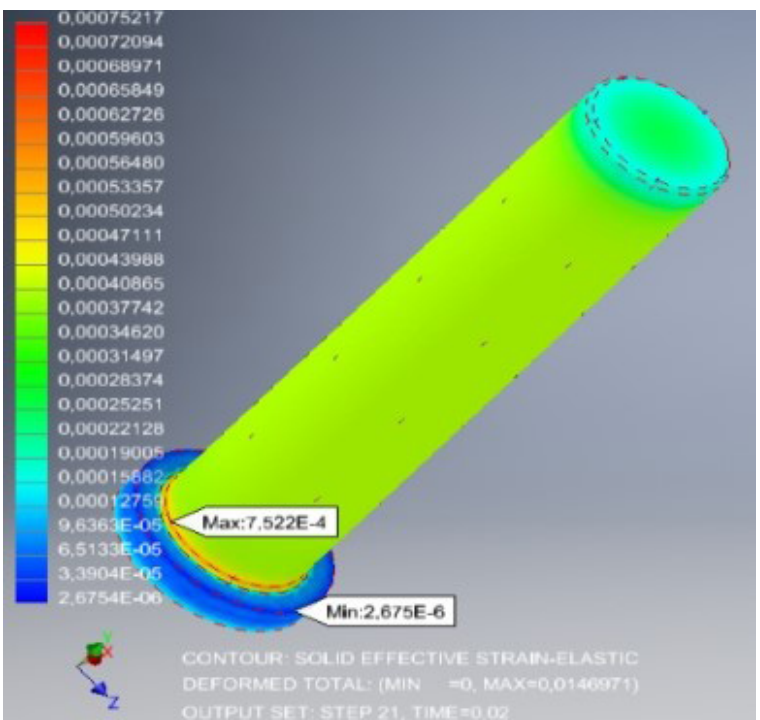

Fig. 13. Strain distribution [-] for the element made from sintered silicon carbide $\mathrm{SSiC}$

the cause of material fatigue, which may lead to crack initiation in the plasticization zone. The causes of non-uniform plastic strain in this element are evidently the cause of their interaction: as a result of friction between the piston and cylinder, non-uniform material hardening, nonuniform temperature distribution and the effect of strain rate. The ultimate results of this process are changes of structural properties, and under the right geometric conditions, upsetting changes the piston's diameter slightly, which has a direct im- 

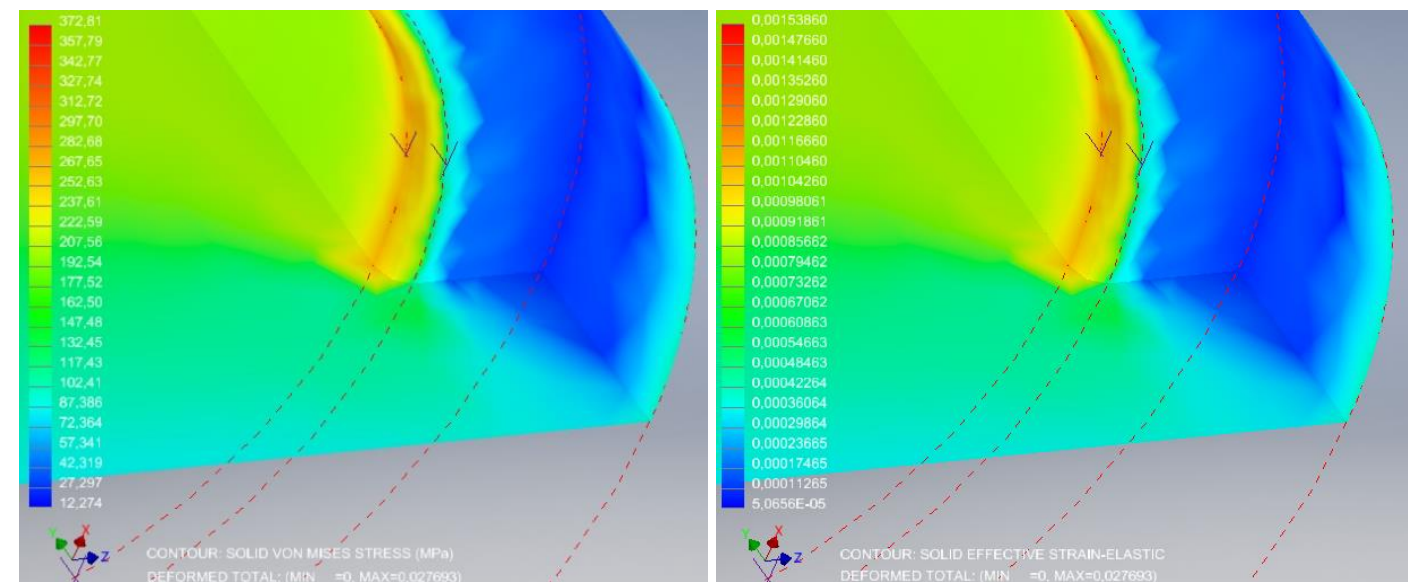

Fig. 14. Concentration of (a) stresses [MPa] and (b) strains [-]

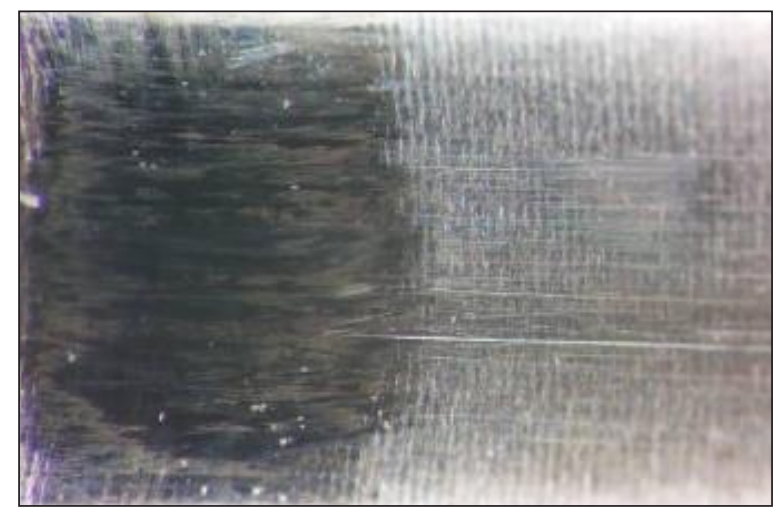

Fig. 15. Piston of CP3 pump with visible upsetting of material

pact on operation - the work of the friction pair's surfaces. It should be emphasized, however, that the yield point taken into consideration to illustrate the example of this type of bearing steel may be greater, e.g. when quenching is applied, $\mathrm{R}_{\mathrm{e}}$ reaches approx. $1300 \mathrm{MPa}$.

\section{CONCLUSIONS}

This article compares selected ceramic materials, $\mathrm{Al}_{2} \mathrm{O}_{3}$ and $\mathrm{SSiC}$, with $100 \mathrm{Cr} 6$ steel. The comparison was conducted with regard to the application of these materials in piston-cylinder pairs of a common rail injection system. Moreover, FEM simulation was conducted, based on applying load to the top part of the piston, which was assigned the properties of the three compared materials. The results of this simulation show that the level of strains in materials is lower for ceramics than for the metal they were compared to.

This is due to the absence of plastic strains in ceramics under the action of loads, and destruc- tion occurs as a result of brittle cracking. The level of strains in $\mathrm{Al}_{2} \mathrm{O}_{3}$ and $\mathrm{SSiC}$ ceramics was lower by one order of magnitude in this analysis.

Assuming the equivalence of compressive and tensile strength, and this simplification is justified when describing elastic-plastic materials, ceramics' significant advantage over steel can be observed. The compressive strength of $\mathrm{Al}_{2} \mathrm{O}_{3}$ and $\mathrm{SSiC}$ is greater than that of $100 \mathrm{Cr} 6$ steel, even if it was subjected to processes improving general strength parameters. It is also possibly to determine critical stresses analytically by replacing yield point $\left(\mathrm{R}_{\mathrm{e}}\right)$ with compressive strength in equation (1). In this way, the clear value limits after which destruction (cracking) of the material occurs is significantly greater than the limits presented by metals. Cracking itself may occur below critical stress values, and this is a special strength aspect of ceramics' application that is worth noting.

In analysis of the product without omission of structural defects, the brittleness index would have to be used to determine threshold load, over which crack propagation occurs [8]. Stresses in the piston generated by compresssive forces close pores being structural defects and weakening the element. Obviously, the results of analysis are mainly dependent on accepted elasticity constants of the material: Young modulus (E) and Poisson's ratio. For a constant surface perpendicular to acting pressure, and thus for the constant diameter of the piston, strain in the test depends on the Young modulus. The greater its value, the lower the strains will be, and the more rigid the element will be. For ceramics, Young modulus is much higher than that of steel, which can be seen in the results of analysis. 
Non-uniform morphology of the structure of ceramics, due to pores, is the cause of notches, which are stress concentration sites to varying extents. The simulation did not account for the presence of structural defects, i.e. cracks, pores, voids. It should be emphasized that the conducted analysis is a certain simplification, since parts with a more complex structure and irregular pores may have different distributions of stress and strain fields in the given material that may be difficult to define properly. This simplification was applied because stress concentration caused by the presence of structural defects is not accounted for when compressive stresses are applied. This means that internal defects do not act on the piston, which is mainly subjected to compressive force, because in such a state, they are closed not opened [12].

\section{Acknowledgement}

This article was financially supported within the project "New generation of common rail pumps" - Lider/015/273/L-5/13/NCBR/2014, implemented within the LIDER Programme, financed by the National Centre for Research and Development, Poland.

\section{REFERENCES}

1. Blicharski M., Inżynieria materiałowa, Wydawnictwa Naukowo-Techniczne, Warszawa 2014.

2. Bosch: Zasobnikowe układy wtryskowe Common
Rail Informator techniczny, Wydawnictwa Komunikacji i Łączności, Warszawa 2009.

3. Dulias U., K.-H. Zum Gahr, Investigation of $\mathrm{Al} 2 \mathrm{O} 3$ - and SSiC-ceramic under lubricated, reciprocating sliding contact and cavitation erosion, Mat.-wiss. u. Werkstofftech., 36, No. 3/4, 2005, 140-147

4. Golewski Grzegorz L., Współczynnik intensywności naprężeń jako podstawowy parametr oceny odporności na pękanie kompozytów betonowych, Drogownictwo, 1/2010, 31-35

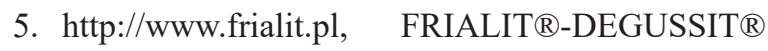
Ceramika Tlenkowa, Materiały, zastosowanie i właściwości, access IV 2017

6. http://www-materials.eng.cam.ac.uk/mpsite/interactive_charts/strength/toughness/ NS6Chart.html, access IV 2017

7. http://www.matweb.com, access IV 2017

8. Kaczorowski M., Krzyńska A.: Konstrukcyjne materiały metalowe, ceramiczne i kompozytowe, Oficyna wydawnicza Politechniki Warszawskiej, Warszawa 2008.

9. Kałdoński T.: Badanie i modelowanie procesów zużywania ściernego hydraulicznych par precyzyjnych. Wojskowa Akademia Techniczna, Warszawa 2008.

10. Karpiuk W., Smolec R.: Zastosowanie biopaliw w układach wtryskowych typu common rail, Logistyka 3/2015, 2090-2101

11. Kuźnicka Bogumiła, Albrecht Ziller, Materiałoznawstwo.

12. Niezgoda T., Małachowski J., Szymczyk W.: Modelowanie numeryczne mikrostruktury ceramiki. Wydawnictwa Naukowo-Techniczne, Warszawa 2005. 